This item was submitted to Loughborough's Research Repository by the author.

Items in Figshare are protected by copyright, with all rights reserved, unless otherwise indicated.

\title{
Key determinants of quality in the pharmaceutical supply chain
}

PLEASE CITE THE PUBLISHED VERSION

https://doi.org/10.1108/ijqrm-06-2020-0213

PUBLISHER

Emerald Publishing Limited

VERSION

AM (Accepted Manuscript)

PUBLISHER STATEMENT

This paper was accepted for publication in the journal International Journal of Quality \& Reliability Management and the definitive published version is available at https://doi.org/10.1108/ijqrm-06-2020-0213.

\section{LICENCE}

CC BY-NC 4.0

\section{REPOSITORY RECORD}

Tayyab, Muhammad, Muhammad Usman Awan, Nadeem Irfan Bukhari, and Ehsan Sabet. 2021. "Key Determinants of Quality in the Pharmaceutical Supply Chain”. Loughborough University.

https://hdl.handle.net/2134/14406323.v1. 


\title{
Key Determinants of Quality in the Pharmaceutical Supply Chain
}

\author{
Muhammad Tayyab \\ University of the Punjab, Pakistan \\ tayyub@hotmail.com \\ Ehsan Sabet \\ Loughborough University, UK \\ Muhammad Usman Awan \\ University of the Punjab, Pakistan \\ Nadeem Irfan Bukhari \\ University of the Punjab, Pakistan
}

\begin{abstract}
Purpose- Empirical studies on the supply chain quality management (SCQM) of pharmaceutical sector are scarce and scattered. This paper investigates a set of key quality determinants in the pharmaceutical sector to offer a holistic quality control framework for its supply chain (SC).

Design/ methodology/ approach- A mixed method design was used. A focused group discussion with seven pharmaceutical SC managers summarised the narratives of the SCQM in this sector and helped to develop a questionnaire. The survey data was collected from the managers of 299 pharmaceutical firms.

Findings- The statistical results show the key determinants are leadership, customer focus, process integration and management, supplier relations, quality practice, human resource practices, and safety. Unlike many other sectors, in the pharmaceutical SC, logistics and inventory costs have been proved to be not as important as other measures in the eyes of the SC managers and as part of SCQM performance measures, which can be a result of the priority systems influenced by the World Health Organisation standards.

Originality/ value- The study is distinctive in its scope as is carried out in a developing country with focus on concept of SCQM with reference to pharmaceutical supply chain. It shows great potential for further studies and improvements in logistics and warehousing in this sector, for the interest of the pharmaceutical SC managers and regulators who aim to ensure safety and quality in the health care sector.
\end{abstract}

Keywords- Supply chain quality, Pharmaceutical supply chain, key quality determinants, Management issues

Article classification- Research paper

\section{Introduction:}

Organizations have long realized that internal operations improvement is only effective when the whole supply chain is competent and competitive (Li et al., 2005; Prado-Prado, 2009). Major 
considerations of customer regarding high quality products, sufficient flexibility and fast delivery are creating challenges for organizations around the world to improve their products to become competitive (Kaur et al., 2019). Integration of supply chain management and quality management has been seen as a panacea for several supply chain problems (Bayraktar et al., 2007).

Researchers consider supply chain quality management (SCQM) as a multidimensional concept involving internal quality management and quality management activities at the level of supply chain (Phan et al., 2019). Managing the quality at supply chain level directly influence improvement in organization's responsiveness to supply chain disruption (Parast, 2020). The organizations are increasingly adapting SCQM in order to improve efficiency, reduce cost, safeguarding competitive advantage and improve customer satisfaction (Phan et al., 2019; Hussain et al., 2020; Karamouz et al., 2020).

The pharmaceutical sector is a key sector in the overall healthcare supply chain. Although the advancements in the pharmaceutical sector have enabled drug manufacturers to produce new and more effective drugs, studies on the its supply chain effectiveness have been significantly lagging behind (Ricci and Fraser, 2006). Fundamental questions, such as what constitutes quality in the pharmaceutical supply chain, have yet been widely open to research (Boyer and Pronovost, 2010; de Blok et al., 2012).

Susceptibility to product recalls in Pharmaceutical supply chain indicates that quality management practices are not fully realized (Zhang et al., 2011). A deeper understanding of SCQM is needed to improve performance in the healthcare industry (Shah et al., 2008). Although a considerable number of supply chain management related studies have been conducted in the healthcare sector (Pan and Pokharel, 2007; Blanchard et al., 2008; Kumar et al., 2008), very few aimed at the pharmaceutical supply chain. Narayana et al., (2012) conducted a content analysis of studies on pharmaceutical supply chain and found that most studies were related to management issues in the pharmaceutical industry, and not the quality aspects. Furthermore, the impact of supply chain quality management on business performance needs to be investigated more extensively in context of developing countries (Phan et al., 2019).

In this study effort has been made to fill the academic gap by developing a holistic quality management model for the pharmaceutical supply chain. To do so, this paper has first reviewed a wide body of the literature to identify a set of critical factors and a framework for the pharmaceutical quality management systems. This framework was then turned to a survey study. The survey was then discussed a group of sector expert in a focused group discourse to adjust the questionnaire. The survey has been conducted in the sector and the results will be discussed in this paper.

The main focus of this study is on the interface between the pharmaceutical manufacturers and its supply chain. The main questions addressed in this study are:

RQ1: What are the critical success factors in pharmaceutical supply chain quality management? 
RQ2: How SCQM relates to supply chain performance and business results in the pharmaceutical sector?

The paper is organized as follows. In the section two, the literature is reviewed in the area of supply chain quality management and supply chain management in healthcare, and summarizes the development of conceptual framework; third, the methodology; fourth, results of the study and the fifth concludes and discusses the results and implications of the study with suggestions for future research.

\section{Theoretical background and conceptual framework:}

\subsection{Supply chain quality management (SCQM):}

Supply chain management (SCM) is a philosophy to integrate vendors, manufacturers, distributors and retailers in a manner to ensure manufacturing and distribution of products at the right time, in right quantities, at the right location, with the common objective of satisfaction of customer requirements and reduction of costs (Simchi-Levi et al., 2008). The goal of supply chain management is to achieve a higher level of synchronization between all partners of the supply chains (Zhang et al., 2011). According to Flynn and Flynn (2004), the quality management practices pursuit is useful in the achievement of the strategic goals including supply chain performance goals of an organization. Vanichchinchai and Igel (2009) compared the two management approaches (TQM and SCM) and concluded that both philosophies have similar ultimate goal and TQM can act as a foundation for implementation of SCM and improving supply performance of firms. Besides, researchers proposed that synergy between SCM and QM leads to improved customer service and product quality (Kannan and Tan, 2007), supply chain performances (Flynn and Flynn, 2005; Vanichchinchai and Igel, 2011; Hussain et al., 2020) and ultimately organizational performance (Lin et al., 2005; Foster and Ogden, 2008). The success of supply chains depends upon the capability of all the chain partners to progress on different aspects of the supply chain quality (Kuei et al., 2011). For a successful supply chain integration, quality plays a vital role in the relationship between the customer and suppliers (Ding et al., 2014; Wu et al., 2014; Zhou et al., 2014).Supply chain quality management (SCQM) is described as a system based approach to improve performance, based on integration, coordination and optimization of activities related to quality among both upstream and downstream members of supply chain (suppliers and customers) with an intent of developing competitive advantage, market share and customer satisfaction by effectively managing quality of products and processes (Robinson and Malhotra, 2005; Foster, 2008; Soares et al., 2017; Phan et al., 2019; Hussain et al., 2020). SCQM positively influence product quality (Kannan and Tan, 2005; Kaur et al., 2019), creates value and attain satisfaction of both intermediate and ultimate customer (Robinson and Malhotra, 2005).

Despite this close association between quality management and supply chain management, such interconnection have not been widely studied (Guanasekaran and McGaughey, 2003; Robinson and Malhotra, 2005). 


\subsection{Supply chain management in the healthcare sector:}

Healthcare is considered as affluent service in most countries (Lanseng and Andreassen, 2007). Among Organization for Economic Co-operation and Development (OECD) member countries, US spent highest percentage of GDP on healthcare sector i.e., 17\% followed by Switzerland (12.3\%), France (11.5\%) and Germany (11.3\%) (Papanicolas et al., 2018). Supply chain management is considered an integral part of healthcare system as it provides the quality care to the patients (Lee et al., 2011). Researchers like Kumar et al. (2008), Mustaffa and Potter (2009), and Shah et al. (2009) have addressed the importance of effective supply chain management in healthcare sector.

The healthcare is regarded as operationally different from other sectors, due to high levels of variability in process (De Vries et al., 1999). Three different factors contribute towards this variability, comprising i) high variation in prescriptions due to presence of different diseases, severity of diseases and individual response to medicines, ii) variations in demands for medicines at each care centre due to unpredictability in patient flow especially emergency department and iii) prescribing habits of clinician due to different preferences, approaches based upon responses, experience, ability, and availability of medicines (Litvak and Long 2000, Noon et al., 2003). As the result, unlike managers of many other industries, managers in the healthcare industry cannot clearly predict demand for medicines and thus swiftly schedule the production (Vissers et al., 2001). In addition to variations and variability in demand and supply in healthcare, the logistics management can also be challenging due to the short shelf-life of the drugs and their tight storage requirements. Just-in-time (JIT) practice cannot be fully implemented as the cost and the risk of inventory shortage is much higher than the cost of excess inventory (Mazzocato, 2007).

Healthcare sector SCM is also facing other challenges, such as outdated supply chain strategies and poor inventory control (Kumar et al., 2008), managing costs while meeting requirements of customers (Hook, 2009), insufficient purchasing information, inadequate purchase procedures and inefficient deliveries (Alt, 1997). The main reason for difficulties in implementation of SCM in healthcare sector is that supply chains of healthcare are: 1) the structure of such value chains are more complicated than other industries (Shah,2004; Scheller and Smeltzer, 2006), 2) behavioral and non-behavioral issues (Narayana et al., 2012), 3) physician and medical experts' limited knowledge about operation management and SCM (Scheller and Smeltzer, 2006), 4) strong regulatory pressure (Shah, 2004), 5) problems in determining accurate sales forecast (Shah, 2004), 6) long lead times that influence supply chain strategies and capacity planning (Shah, 2004), 7) difficult to predict patient mix and medicine consumption by ultimate customers (Scheller and Smeltzer, 2006), 8) different organizational culture within the healthcare chains (McCutcheon and Stuart, 2000). All of the above issues make value chain of healthcare more complex and dynamic (Evans and Berman, 2001) than many other chains. Healthcare value chain concept is pressurising organizations to look for opportunities to improve operational efficiencies and reduce costs while continuously improving quality of care provided to patients (Hanna and Sethuraman, 2005). 
Application of TQM leads to enhanced patient satisfaction, better morale of employees, higher quality care, and increased profitability and productivity (Alexander et al., 2006; Cauchick, 2006; Macinati, 2008). Many healthcare organizations have applied TQM principles and strategies to improve the healthcare service efficiency delivery and outcome's quality (Kunst and Lemmink, 2000; Macinati, 2008).

Marinkovic et al. (2016) concluded in their empirical study on TQM implementation in the pharmaceutical industry that quality of medicines cannot be separated from the safety of a patient; hence customer focus in the pharmaceutical business is more complex than other sectors as regulatory authorities involved in the link between health professionals and pharmaceutical organizations and ultimately the patients. Pharmaceutical manufacturing industries are regulated by the quality standards of Good Manufacturing Practices (GMP). The GMP standard focuses on the manufacturing of quality and safe medicines suitable for human consumption (Greene and O'Rourke, 2006).

A typical pharmaceutical supply chain of healthcare sector consists of the following components as shown in Figure 1 (Shah, 2004; Schneller and Smeltzer, 2006):

1) Primary manufacturing (supplier of the active ingredient)

2) Secondary manufacturing (production of finished products)

3) Distributors/wholesalers

4) Retailers/ hospitals

5) Customer (individual, government, employers)

The focus of this study is on the interface of the medicine manufacturer and the rest of the pharmaceutical supply chain.

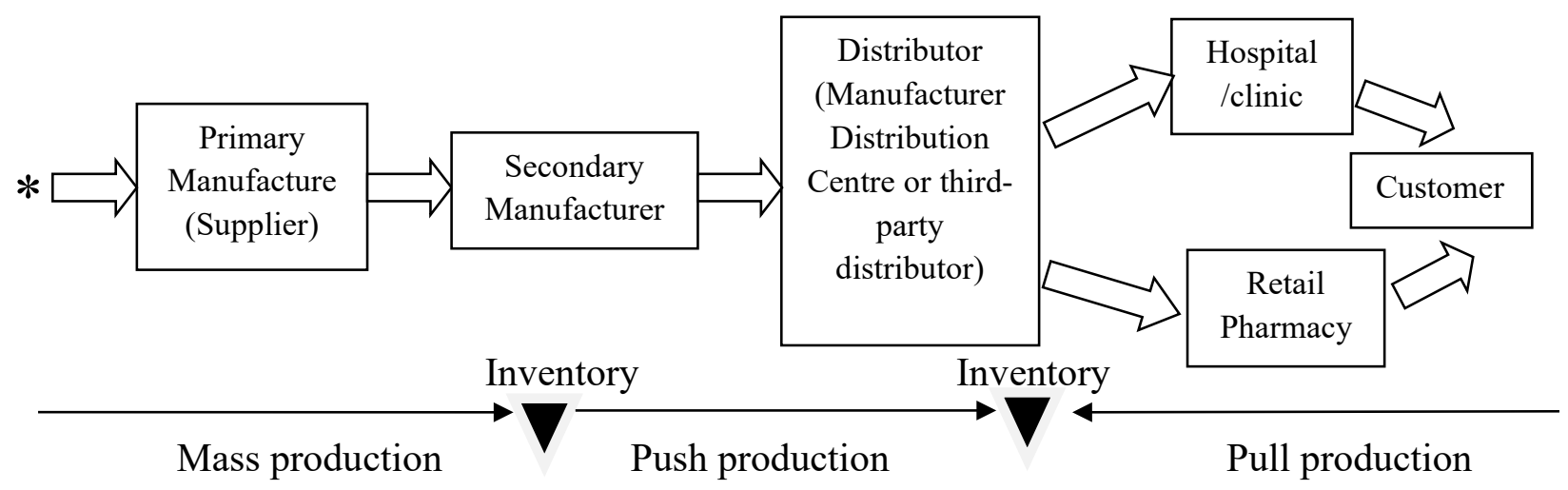

Adopted from Morton (2003) and Shah (2004)

Figure.1: The typical structure for healthcare sector pharmaceutical supply chains * Primary manufacturer (supplier) can receive basic components of raw material from another supplier 


\subsection{Conceptual framework:}

Seven themes/ critical factors are identified after comprehensive literature review of supply chain quality management studies as shown in Table I i.e., leadership (LS), human resource practices (HRP), quality practices (QP), supplier relations (strategic supplier partnerships) (SR), customer focus (CF), safety (SF) and process integration and management (PIM). In this study, the relationship between these seven supply chain quality management themes and the supply chain and business performance of the pharmaceutical supply chain is investigated.

Table I: Critical factors of SCQM

\begin{tabular}{|c|c|c|c|c|c|c|c|}
\hline Studies & Leadership & $\begin{array}{l}\text { Human } \\
\text { resource } \\
\text { practices }\end{array}$ & $\begin{array}{l}\text { Supplier } \\
\text { relations/ } \\
\text { supplier } \\
\text { managem } \\
\text { ent }\end{array}$ & $\begin{array}{l}\text { Quality } \\
\text { practices }\end{array}$ & $\begin{array}{l}\text { Customer } \\
\text { focus }\end{array}$ & Safety & $\begin{array}{l}\text { Process } \\
\text { integration } \\
\text { and } \\
\text { management }\end{array}$ \\
\hline $\begin{array}{l}\text { Kuei and } \\
\text { Madu } \\
\text { (2001) }\end{array}$ & & & $\sqrt{ }$ & & $\sqrt{ }$ & & \\
\hline $\begin{array}{l}\text { Flynn and } \\
\text { Flynn } \\
(2005)\end{array}$ & $\sqrt{ }$ & $\sqrt{ }$ & $\sqrt{ }$ & & $\sqrt{ }$ & & $\sqrt{ }$ \\
\hline $\begin{array}{l}\text { Lin et al. } \\
(2005)\end{array}$ & & & $\sqrt{ }$ & $\sqrt{ }$ & & & \\
\hline $\begin{array}{l}\text { Robinson } \\
\text { and } \\
\text { Malhotra } \\
(2005)\end{array}$ & $\sqrt{ }$ & & & $\sqrt{ }$ & & & $\sqrt{ }$ \\
\hline $\begin{array}{l}\text { Das et al. } \\
(2008)\end{array}$ & & & & $\sqrt{ }$ & & $\sqrt{ }$ & \\
\hline $\begin{array}{l}\text { Foster } \\
(2008)\end{array}$ & $\sqrt{ }$ & $\sqrt{ }$ & $\sqrt{ }$ & $\sqrt{ }$ & $\sqrt{ }$ & $\sqrt{ }$ & \\
\hline $\begin{array}{l}\text { Kaynak and } \\
\text { Hartley } \\
\text { (2008) }\end{array}$ & $\sqrt{ }$ & $\sqrt{ }$ & $\sqrt{ }$ & $\sqrt{ }$ & $\sqrt{ }$ & & $\sqrt{ }$ \\
\hline $\begin{array}{l}\text { Kuei et al. } \\
(2008)\end{array}$ & $\sqrt{ }$ & & $\sqrt{ }$ & $\sqrt{ }$ & $\sqrt{ }$ & & $\sqrt{ }$ \\
\hline $\begin{array}{l}\text { Sroufe and } \\
\text { Curkovic } \\
\text { (2008) }\end{array}$ & & $\sqrt{ }$ & $\sqrt{ }$ & $\sqrt{ }$ & $\sqrt{ }$ & & \\
\hline $\begin{array}{l}\text { Yeung } \\
(2008)\end{array}$ & & & $\sqrt{ }$ & $\sqrt{ }$ & $\sqrt{ }$ & & \\
\hline $\begin{array}{l}\text { Chang } \\
\text { (2009) }\end{array}$ & $\sqrt{ }$ & & $\sqrt{ }$ & $\sqrt{ }$ & $\sqrt{ }$ & & $\sqrt{ }$ \\
\hline Fish (2011) & $\sqrt{ }$ & $\sqrt{ }$ & & $\sqrt{ }$ & $\sqrt{ }$ & & $\sqrt{ }$ \\
\hline $\begin{array}{l}\text { Foster } \text { et al. } \\
\text { (2011) }\end{array}$ & $\sqrt{ }$ & $\sqrt{ }$ & $\sqrt{ }$ & $\sqrt{ }$ & $\sqrt{ }$ & & $\sqrt{ }$ \\
\hline
\end{tabular}




\begin{tabular}{|c|c|c|c|c|c|c|c|}
\hline $\begin{array}{l}\text { Kuei et al. } \\
\text { (2011) }\end{array}$ & $\sqrt{ }$ & $\sqrt{ }$ & & $\sqrt{ }$ & $\sqrt{ }$ & & $\sqrt{ }$ \\
\hline $\begin{array}{l}\text { Rashid and } \\
\text { Aslam } \\
\text { (2012) }\end{array}$ & $\sqrt{ }$ & $\sqrt{ }$ & $\sqrt{ }$ & $\sqrt{ }$ & $\sqrt{ }$ & & $\sqrt{ }$ \\
\hline $\begin{array}{l}\text { Zu and } \\
\text { Kaynak } \\
(2012)\end{array}$ & & & $\sqrt{ }$ & & & & \\
\hline $\begin{array}{l}\text { Chai et al. } \\
\text { (2013) }\end{array}$ & $\sqrt{ }$ & $\sqrt{ }$ & $\sqrt{ }$ & $\sqrt{ }$ & & & $\sqrt{ }$ \\
\hline $\begin{array}{l}\text { Lin et al. } \\
\text { (2013) }\end{array}$ & $\sqrt{ }$ & $\sqrt{ }$ & $\sqrt{ }$ & $\sqrt{ }$ & & & $\sqrt{ }$ \\
\hline $\begin{array}{l}\text { Parast } \\
(2013)\end{array}$ & $\sqrt{ }$ & & & $\sqrt{ }$ & $\sqrt{ }$ & & $\sqrt{ }$ \\
\hline $\begin{array}{l}\text { Zeng et al. } \\
\text { (2013) }\end{array}$ & $\sqrt{ }$ & & $\sqrt{ }$ & $\sqrt{ }$ & $\sqrt{ }$ & & $\sqrt{ }$ \\
\hline $\begin{array}{l}\text { Huo et al. } \\
(2016)\end{array}$ & & & $\sqrt{ }$ & $\sqrt{ }$ & $\sqrt{ }$ & & \\
\hline $\begin{array}{l}\text { Quang et } \\
\text { al. (2016) }\end{array}$ & $\sqrt{ }$ & $\sqrt{ }$ & $\sqrt{ }$ & & $\sqrt{ }$ & & $\sqrt{ }$ \\
\hline $\begin{array}{l}\text { Sarrico and } \\
\text { Rosa } \\
(2016)\end{array}$ & $\sqrt{ }$ & & & & & & $\sqrt{ }$ \\
\hline $\begin{array}{l}\text { Fernandes } \\
\text { et al. } \\
\text { (2017) }\end{array}$ & $\sqrt{ }$ & & $\sqrt{ }$ & $\sqrt{ }$ & & & \\
\hline $\begin{array}{l}\text { Bastas and } \\
\text { Liyanage } \\
\text { (2018) }\end{array}$ & $\sqrt{ }$ & $\sqrt{ }$ & & & $\sqrt{ }$ & & $\sqrt{ }$ \\
\hline $\begin{array}{l}\text { Teoman } \\
\text { and } \\
\text { Ulengin } \\
\text { (2018) }\end{array}$ & $\sqrt{ }$ & $\sqrt{ }$ & $\sqrt{ }$ & & $\sqrt{ }$ & & \\
\hline $\begin{array}{l}\text { Yu and } \\
\text { Huo (2018) }\end{array}$ & & & $\sqrt{ }$ & & $\sqrt{ }$ & & \\
\hline $\begin{array}{l}\text { Phan et al., } \\
\text { (2019) }\end{array}$ & $\sqrt{ }$ & & $\sqrt{ }$ & $\sqrt{ }$ & $\sqrt{ }$ & & $\sqrt{ }$ \\
\hline $\begin{array}{l}\text { Hong et al., } \\
(2020)\end{array}$ & & & & $\checkmark$ & $\sqrt{ }$ & $\sqrt{ }$ & \\
\hline $\begin{array}{l}\text { Hussain et } \\
\text { al., (2020) }\end{array}$ & $\sqrt{ }$ & & $\sqrt{ }$ & & $\sqrt{ }$ & & \\
\hline $\begin{array}{l}\text { Kaur et al., } \\
\text { (2019) }\end{array}$ & $\sqrt{ }$ & & $\sqrt{ }$ & & $\sqrt{ }$ & & \\
\hline $\begin{array}{l}\text { Kumar } e t \\
\text { al., (2020) }\end{array}$ & $\sqrt{ }$ & $\sqrt{ }$ & & & $\sqrt{ }$ & & \\
\hline
\end{tabular}




\subsubsection{Leadership:}

Leadership plays an important role in supply chain quality management by supporting change initiatives through employee motivation, quality planning, and provision of resources and training to support these initiatives (Das et al., 2008; Teoman and Ulengin, 2018; Kaur et al., 2019; Kumar et al., 2020). It is responsibility of leadership to communicate vision and quality policy to develop and organize quality initiatives and goals to continuously improve (Rashid and Aslam, 2012). Top management supports provide the main driver towards an effective and successful implementation of SCQM through integration and collaboration (Fish, 2011; Hussain et al., 2020; Kumar et al., 2020).

\subsubsection{Customer focus:}

It involves how well organizations develop the system to determine current and emerging requirements and expectations of customers, translate them into organizational goals, build relationships with customers, measures customer satisfaction and utilize customer feedback in quality and service improvement (Bastas and Liyanage, 2018; Teoman and Ulengin, 2018; Kaur et al., 2019; Hong et al., 2020).

\subsubsection{Process integration and management:}

Process integration is a set of continuous activities with an aim to link business processes seamlessly and reduce unnecessary or redundant processes within or across organizations. Process integration in the context of the supply chain quality management is defined as linking of external and internal activities (Robinson and Malhotra, 2005), fool proof process design and involves policies, procedures and practices that control the process with the objective of value addition in systems and reduction of cycle inventories and safety stocks (Flynn and Flynn, 2005; Bastas and Liyanage, 2018).

\subsubsection{Supplier Relations:}

Often, purchased materials are considered as the major source of quality problems. Supplier relationships encourage suppliers to get involved in product or service design and process improvements leading to improved quality of products and services (Kaynak and Hartley, 2008; Kuei et al., 2011; Kaur et al., 2019). Supply-base rationalization processes can be improved by improving supply chain quality management, because when product quality is improved, variation between supplies is reduced and integration can be facilitated (Fish, 2011; Hong et al., 2020).

\subsubsection{Quality Practices:}

Establishment of a quality-based culture in supply chains can improve customer satisfaction, financial performance and operational performance along the supply chain (Kaynak and Hartley, 2008). Systemic share of information, knowledge and quality systems among members of a supply chain improves the internal operations and quality of the firm (Hong et al., 2020). In 
order to sustain quality improvement effort across the chain, the entire chain must share the same the same practices and quality systems at all organizational levels (Bastas and Liyanage, 2018).

\subsubsection{Human Resource Practices:}

Human resource management in context of supply chain quality management can be measured by indicators like creation of good working environment for employees, employee training to improve their learning for utilization of quality improvement tools and techniques, employee empowerment, employee participation in quality decisions, use of cross-functional teams and communication within company (Fish, 2011; Bastas and Liyanage, 2018; Kumar et al., 2020). The role of human resource management in the supply chain has been loosely addressed as compared to its importance emphasized by quality management through practices such as employee involvement and employee training (Flynn and Flynn, 2005; Kumar et al., 2020). Effective skill development trainings of employees are essential to manage the partnerships and relationships in supply chain quality management (Fish, 2011).

\subsubsection{Safety:}

Perception of workplace safety plays an important role in the motivation of workers and result into quality outcomes (scrap, rework and reliability) in supply chains (Das et al., 2008), and it may be of significant importance in Pharmaceutical supply chain where employees deal with chemicals and drugs.

\subsubsection{Relationship of SCQM with supply chain performance and business results:}

Approaches of quality management help to improve supply chain performance (Foster and Ogden, 2008; Phan et al., 2019; Kumar et al., 2020). Supply chain performance in term of cost, delivery and quality of products can only be achieved if all nodes of supply chain are completely integrated (Li et al., 2006; Qurunfleh and Tarafdar, 2014).

Improved supply chain performance (increased productivity, reduction of defective products, decreased cost of quality and on-time delivery of products) leads to enhanced business performance (Benner and Veloso, 2008; Lee et al., 2012). Kaynak (2003) proposed that improved supply chain performance enables organizations to produce quality products and earn revenues and profits. It means supply chain performance plays mediating role to improve financial performance of organizations.

However, many academics agree with the view that high quality product quality is positively associated with business results of organizations i.e., market share (Buchanan and Gillies, 1990), increased profit and sales margin (Heras et al., 2002). Lin et al. (2005) used sales growth, productivity, profitability, market share and earnings growth as indicators of business results in their study on SCQM. Other popular measures used in supply chain management literature are return on investment (ROI) (Lin et al., 2005; Flynn et al., 2010), return on equity (ROE) (Hitt et al., 2002) and return on assets (ROA) (Lanier et al., 2010).

In this study we have proposed a research framework as shown in Figure. 2, comprising of seven factors that constitute theme of SCQM and relation of SCQM with supply chain performance and 
business results. SCQM can influence both performances directly or may be supply chain performance acts as mediator in relationship between SCQM and business results.

In accordance with the conceptual framework, the hypotheses of the research were as follows:

H1: Supply chain quality management has positive impact on pharmaceutical supply chain performance.

H2: Supply chain quality management has positive impact on business results.

H3: Supply chain quality management has positive impact on business results through supply chain performances improvement.

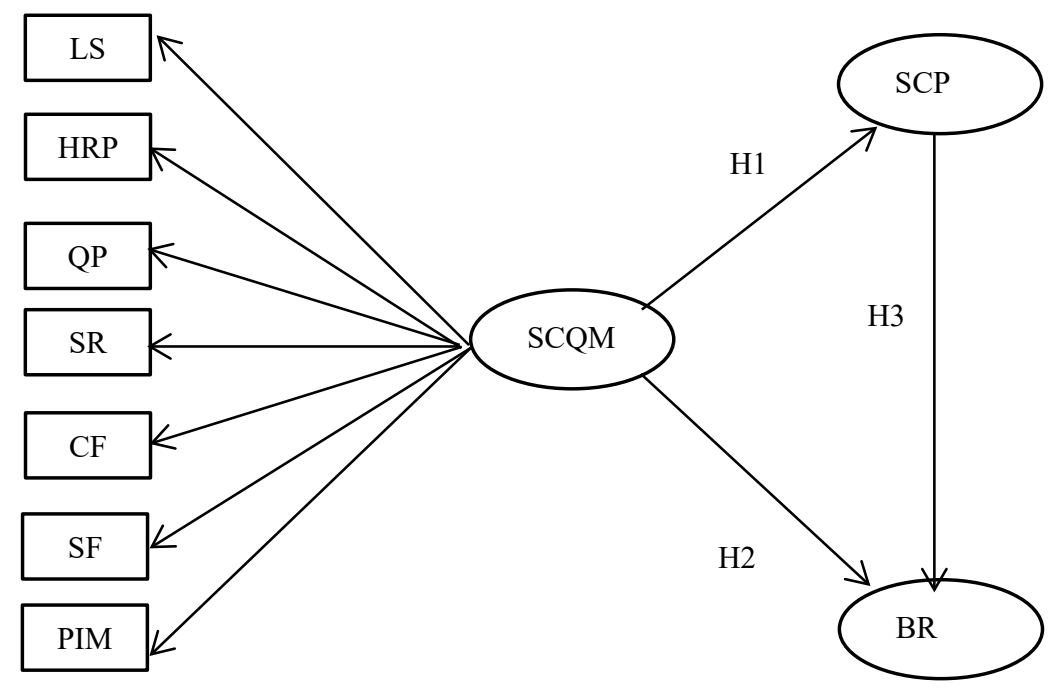

\begin{tabular}{|l|c|}
\hline Leadership & LS \\
\hline Human resource practices & HR \\
\hline Quality practices & QP \\
\hline $\begin{array}{l}\text { Supplier Relations: (strategic supplier } \\
\text { partnership) }\end{array}$ & SR \\
\hline Customer focus & CF \\
\hline Safety & SF \\
\hline Process Integration and Management & PIM \\
\hline Business results & BR \\
\hline Supply chain performances & SCP \\
\hline
\end{tabular}

Figure 2: Theoretical path model 


\section{Methodology:}

Mixed methods sequential research strategy was adapted for this study, as it creates a synergistic research project whereby one method enables the other to be more effective and together both methods provide a full understanding of research problem (Greene and Caracelli, 1997; Creswell and Clark, 2017). Sequential mixed methods strategy may involve beginning with qualitative interviews or focus group discussions for exploratory purpose, followed by quantitative survey method with a large sample size for generalization of results to a population (Creswell, 2005). In this study focus group (qualitative) is used as a preliminary method for refinement of measurement scale developed from published literature. Then a survey method is used to collect quantifiable data from a larger population.

Focus group methodology has gained popularity in primary healthcare research (Hendrickx et al., 2009). Morgan (1993) suggested the use of a focus group to refine the survey questionnaire for the new population by keeping in view the sector and country-specific scenario. Seven representatives including Plant/operational managers, Quality Assurance Managers and Marketing Mangers from seven different pharmaceutical manufacturing organizations in Pakistan participated in our focus group discussion. One of the researchers acted as a moderator for the focus group discussion. Two issues were discussed in the focus group. One was a refinement of title and number of constructs and the second was to refine items in each of the constructs. A questionnaire comprising of 64 items (found by the literature review) was discussed in the focus group for further refinement in the context of manufacturer interface of pharmaceutical SCQM.

On the recommendation of focus group participants language of survey questionnaire was simplified to make it more understandable by the variety of the respondents. Changes in the questionnaire proposed by focus group participants were done in real time and showed to participants to ensure member checking. At the end of the focus group, the moderator presented the final draft of questionnaire to the participants for their confirmation. The emerged scale after focus group discussion consisted of 45 items. Majority of the items belong to supply chain quality management constructs and few related to supply chain performance $\&$ business results. The questionnaire comprised only of closed-end questions. All variables of interest were estimated through respondent's perceptual evaluation on five-point Likert scale: the response categories for each item were 1very low and 5 very high. A copy of the questionnaire is available upon asking the corresponding author.

The total number of pharmaceutical manufacturing units registered in Pakistan is 665 (Pakistan National Health Accounts Report, 2014). For survey research, probability (random) sampling is preferred over non-probability sampling (Saunders et al., 2000). However, according to Trochim (2006), there may be situations where it is neither theoretically sensible nor practically feasible to carry out probability sampling. The concept of supply chain quality management is underdeveloped in developing economies like Pakistan (Rashid and Aslam (2012; Phan et al., 2019), and due to the lack of a reliable sampling frame for each interface, non-probability purposive sampling used to collect the data. Purposive sampling is also 
considered as suitable sampling technique in situations where the main object of study is to get opinions of respondents with specific experience and expertise without considering the proportion of the population. Majority of pharmaceutical manufacturing plants are running in big cities of Pakistan as compared to the rest of the country. Sampling was carried out in Karachi, Lahore, Islamabad, and Faisalabad. The target respondents were the CEOs, supply chain / operations managers, quality assurance managers and the marketing manager. After 30 days reminder emails were sent to the respondents who didn't respond. Responses were returned by respondents in a time period of 16 weeks. None of questions were kept in ideal number to avoid respondent fatigue. 299 responses were received out of 500 distributed questionnaire indicating $59.80 \%$ response rate.

Constructs were labelled in accordance with the theoretical research model. Outliers were screened out and normality of data checked. Reliability is the extent to which a variable or set of variables consistent in intended measurement (Hair et al., 1998). Several measures are often used for assessment of reliability, and in this research, Cronbach's Alpha and inter-item correlations was used to check internal consistency or reliability of measurement items. The Cronbach's alpha value above 0.7 and item correlation value exceeding 0.3 is considered as the good value of internal consistency (Nunnally and Burnstein, 1994; Hair et al., 1998). Structural equation modelling is used to test the hypothesized model. SEM is a broad data analysis technique having unique and flexible capabilities that provide overall testing of model fit and calculate individual parameter estimate simultaneously (Tomarken and Waller, 2005). It is preferred by the researchers because it estimates the multiple and interrelated dependence in a single analysis. AMOS software, version 24, is employed to conduct Confirmatory factor analysis (CFA) of constructs. Researchers suggest that the minimum number of cases for structural equation modelling (SEM) should be at least five times of items to be analysed (Hair et al, 1998) so the sample size is well above minimum limit of 5:1 to the variables in the questionnaire. CFA was carried out to ensure uni-dimensionality of the scale, reliability and construct assessment (Anderson and Gerbing, 1982). The CFA with Maximum Likelihood Estimation (MLE) was employed to evaluate the validity of models. It is the most commonly used method of estimation and is preferably used when the sample size is at least 200 and at least three items of every construct (Hair et al., 1998). In this study sample size of 299 qualifies the requirement of the method. All the constructs used in the study have a minimum of three items.

Different measures of model fit have been used by researchers to evaluate hypothesized models. Hu and Bentler (1999) suggested combination of relative fit indices such as CFI or IFI (value more than 0.95) with SRMR (value less than 0.08) or RMSEA (value less than 0.06) to minimize Type I and II errors. They preferred CFI with SRMR on TLI/RMSEA when sample size is less than or equal to 250. McDonald and Ho (2002) recommended use of CFI, GFI, NFI and NNFI (TLI). GFI and AGFI measures should not be used as they are affected by sample size (Sharma et al., 2005). TLI and IFI are relatively unaffected by sample size (Gerbing and Anderson, 1993; Hu and Bentler, 1999). Kline (2005) suggested SRMR, RMSEA, CFI, Chisquare, df value and $p$-value for evaluation of model. p-value is rarely used in empirical studies 
in either management field or operations management specifically (Das et al., 2000; Frohlich, 2002; Lai, 2003). Normed chi-square ( $\left.\mathrm{x}^{2} / \mathrm{df}\right)$ with standard value of less than 3 (Byrne, 1998) or less than 5 (Wheaton et al., 1977) is preferred over chi square index.

RMSEA and CFI are highly recommended fit indices but despite of sensitivity to sample size GFI and AGFI are among frequently used indices (Bollen, 1989). Lei and Wu (2007) used the standardized root mean square residual (SRMR), the root mean square error of approximation (RMSEA), confirmatory fit index (CFI) and likelihood ratio chi-square goodness of fit statistic. According to Sila and Ebrahimpour (2005), CFA should be assessed by using criteria of RMSEA, CFI and GFI. To assess the overall goodness of fit of each construct four type of fit indices were employed i.e.; 1) Normed Chi-square ( x2/df ratio) 2) Comparative fit index (CFI) or Bentler Comparative Fit Index 3) Non-Normed Fit Index (NNFI) or Bentler-Bonett Non Normed Fit index or Tucker-Lewis index (TLI) and 4) Standardized Root Mean Squared Residual (SRMR).

All the individual measurement models were tested for convergent validity with CFA in order to remove weak loading coefficients below 0.5 (Hair et al., 2010) and determine unidimensionality of the scale items. In SEM, factor loadings and average variance extracted (AVE) should be greater than 0.5 to establish convergent validity (Fornell and Larcker, 1981). Composite reliability should be greater than the limit of 0.7 (Fornell and Larcker, 1981). Discriminant validity of first order constructs was checked by comparing square root of AVE of each factor with correlations between pair of latent variables (Fornell and Larcker, 1981; Gerbing and Anderson, 1993).

After reliability and validity analysis structural equation modelling was employed for model estimation and testing of research framework for SCQM relationship with business results and supply chain performances. Maximum likelihood estimation method was used to estimate path coefficients of the structural model.

\section{Results:}

To address the first research question, along with literature review expert's opinion in form of focus group discussion was employed. Seven success factors of supply chain quality management consisting of 64 items were identified from comprehensive literature review. All the participants agreed with the title and number of constructs but few items were modified or dropped from the constructs of Human Resource Practices, Quality Practices, Supplier Relations, Customer Focus, Process Integration \& Management and Supply Chain Performances due to the lack of relevance and the importance in the context of the pharmaceutical manufacturing organizations. The emerged scale after focus group discussion consisted of 45 items. Market share, return on investment and net profit level emerged as measures of business results, while, transportation cost, warehousing cost, demand forecast, quality of products, order lead time, planning cycle time, waste generation, and product warranty claims as measures of supply chain performance in context of SCQM (Thai and Jie, 2018; Phan et al., 2019; Hussain et al., 2020; Karamouz et al.,2020). 
The data collected after survey was analysed with the help of AMOS . No missing value found in the data set. Kim (2013) recommended use of z-score values when the sample size is below 300. Data points outside z-score value of \pm 2.5 were identified as outliers and have been deleted, leaving 299 usable responses. All values in the usable data were lying between the standard range of \pm 2 (Field, 2000; Trochim and Donnelly, 2006) for both skewness and kurtosis proving normal univariate distribution of data. Maximum skewness value of -0.596 for BR and the minimum value of -0.197 for $\mathrm{QP}$ and maximum kurtosis value of -0.481 for $\mathrm{CF}$ and minimum value of- 0.037 for LS was observed. Q-Q plots and histograms with normality plots were also drawn to confirm normal distribution of data points (see Figure 3).
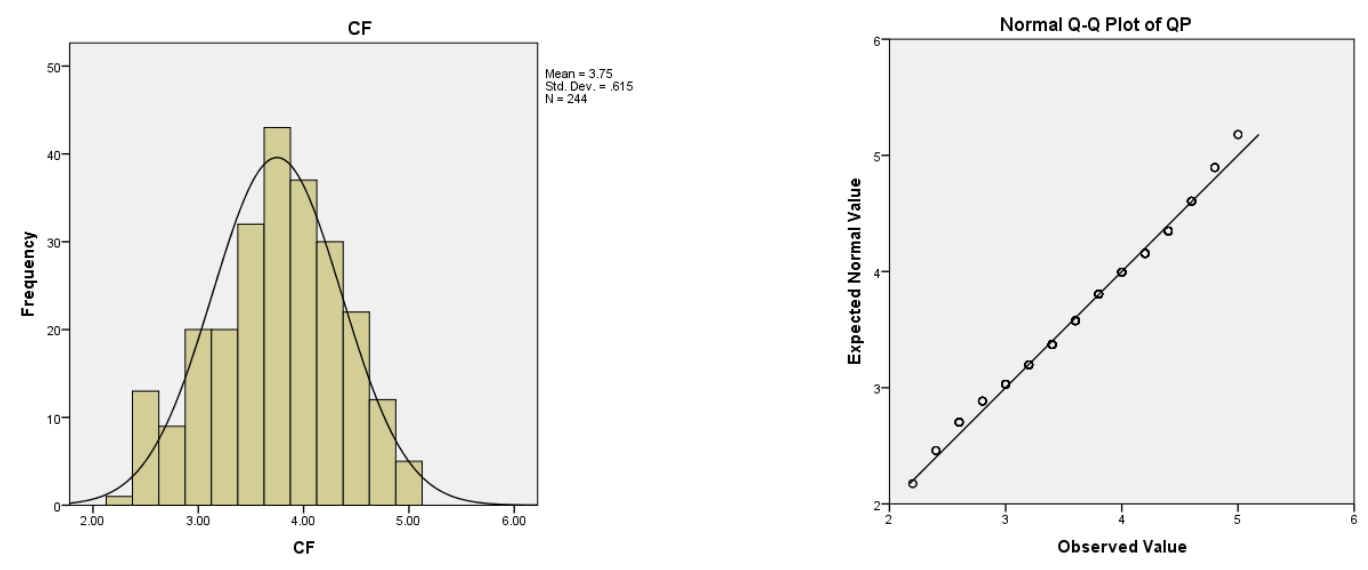

Figure 3: Histogram with normality plot and Q-Q plot

All items of seven constructs of SCQM, supply chain performance and business results constructs have shown more than 0.7 value for Cronbach's alpha and 0.3 score of inter-item correlation. The highest item-total correlation belonged to LS5 i.e., 0.683 and lowest to SR4 at 0.393. SCP had highest Cronbach's alpha value of 0.853 and CF lowest with the value of 0.735 . Reliability of the whole questionnaire was 0.953 .

All items of seven constructs of SCQM and Business Results had loading coefficients exceeding 0.5 value so no item had to be deleted but two items SCP1 and SCP2 belonging to Supply chain performance construct were removed due to weak loading coefficients i.e., 0.46 and 0.43 respectively (see Table II). All the models had average variance extracted (AVE) value more than 0.50 and composite reliability (CR) above 0.7 (Shook et al., 2004), suggesting good convergent validity as shown in Table III.

Table II: SCP items dropped due to low standardized loading coefficients.

\begin{tabular}{|l|l|}
\hline Items & Description \\
\hline SCP1 & Cost associated with transportation of goods is reduced. \\
\hline SCP2 & Warehousing cost is reduced. \\
\hline
\end{tabular}


All the constructs passed the standard limits. Supplier Relations (SR) construct had TLI value $=0.87$ less than standard value and a $p$-value less than 0.05 but values of rest of indexes were good so it can be considered as acceptable fit. For SR one fit index AGFI was also included to evaluate model fitness. AGFI value of 0.89 above the standard value of 0.80 (Kline, 2005) confirmed model fitness.

Table III: Results of Convergent Validity

\begin{tabular}{|c|c|c|c|c|c|c|c|c|c|}
\hline Constructs & items & $\begin{array}{l}\text { Standardized } \\
\text { Loadings } \\
\text { coefficient }\end{array}$ & $\begin{array}{l}\text { Composite } \\
\text { Reliability } \\
\text { (CR) }\end{array}$ & $\begin{array}{l}\text { Average } \\
\text { Variance } \\
\text { Extracted } \\
\text { (AVE) }\end{array}$ & $\mathrm{x}^{2} / \mathrm{df}$ & p-value & CFI & TLI & $\overline{\text { SRMR }}$ \\
\hline \multirow[t]{2}{*}{ LS } & LS1 & 0.85 & \multirow[t]{5}{*}{0.89} & \multirow[t]{5}{*}{0.64} & \multirow[t]{5}{*}{1.46} & \multirow[t]{5}{*}{0.200} & \multirow[t]{5}{*}{0.99} & \multirow[t]{5}{*}{0.99} & \multirow[t]{5}{*}{0.0241} \\
\hline & LS2 & 0.82 & & & & & & & \\
\hline \multirow[t]{3}{*}{$\alpha=0.798$} & LS3 & 0.75 & & & & & & & \\
\hline & LS4 & 0.81 & & & & & & & \\
\hline & LS5 & 0.77 & & & & & & & \\
\hline \multirow{4}{*}{$\alpha=0.779$} & $\begin{array}{l}\text { HRP } \\
1\end{array}$ & 0.90 & \multirow[t]{4}{*}{0.83} & \multirow[t]{4}{*}{0.51} & \multirow[t]{4}{*}{2.25} & \multirow[t]{4}{*}{0.134} & \multirow[t]{4}{*}{1.00} & \multirow[t]{4}{*}{0.98} & \multirow[t]{4}{*}{0.0127} \\
\hline & $\begin{array}{l}\text { HRP } \\
2\end{array}$ & 0.79 & & & & & & & \\
\hline & $\begin{array}{l}\text { HRP } \\
3\end{array}$ & 0.54 & & & & & & & \\
\hline & $\begin{array}{l}\text { HRP } \\
4\end{array}$ & 0.55 & & & & & & & \\
\hline \multirow[t]{2}{*}{ QP } & QP1 & 0.85 & \multirow[t]{5}{*}{0.86} & \multirow[t]{5}{*}{0.52} & \multirow[t]{5}{*}{1.10} & \multirow[t]{5}{*}{0.359} & \multirow[t]{5}{*}{1.0} & \multirow[t]{5}{*}{1.0} & \multirow[t]{5}{*}{0.0235} \\
\hline & QP2 & 0.70 & & & & & & & \\
\hline \multirow[t]{3}{*}{$\alpha=0.756$} & QP3 & 0.68 & & & & & & & \\
\hline & QP4 & 0.74 & & & & & & & \\
\hline & QP5 & 0.62 & & & & & & & \\
\hline \multirow[t]{2}{*}{ SR } & SR1 & 0.84 & \multirow[t]{7}{*}{0.89} & \multirow[t]{7}{*}{0.54} & \multirow[t]{7}{*}{3.43} & 0.000 & 0.92 & 0.87 & 0.0531 \\
\hline & SR2 & 0.70 & & & & & & & \\
\hline$\alpha=0.781$ & SR3 & 0.69 & & & & & & & \\
\hline & SR4 & 0.68 & & & & & & & \\
\hline & SR5 & 0.73 & & & & & & & \\
\hline & SR6 & 0.75 & & & & & & & \\
\hline & SR7 & 0.75 & & & & & & & \\
\hline $\mathrm{CF}$ & $\mathrm{CF} 1$ & 0.82 & 0.85 & 0.60 & 1.48 & 0.228 & 1.0 & 0.99 & 0.0216 \\
\hline & CF2 & 0.80 & & & & & & & \\
\hline$\alpha=0.735$ & CF3 & 0.78 & & & & & & & \\
\hline & $\mathrm{CF} 4$ & 0.68 & & & & & & & \\
\hline $\mathrm{SF}$ & SF1 & 0.78 & 0.87 & 0.61 & 3.93 & 0.020 & 0.98 & 0.97 & 0.0287 \\
\hline & SF2 & 0.80 & & & & & & & \\
\hline$\alpha=0.822$ & SF3 & 0.77 & & & & & & & \\
\hline
\end{tabular}




\begin{tabular}{|c|c|c|c|c|c|c|c|c|c|}
\hline \multirow[t]{2}{*}{ PIM } & PIM1 & 0.81 & \multirow[t]{6}{*}{0.90} & \multirow[t]{6}{*}{0.62} & \multirow[t]{6}{*}{1.64} & \multirow[t]{6}{*}{0.098} & \multirow[t]{6}{*}{0.99} & \multirow[t]{6}{*}{0.98} & \multirow[t]{6}{*}{0.0300} \\
\hline & PIM2 & 0.79 & & & & & & & \\
\hline \multirow[t]{4}{*}{$\alpha=0.812$} & PIM3 & 0.79 & & & & & & & \\
\hline & PIM4 & 0.78 & & & & & & & \\
\hline & PIM5 & 0.85 & & & & & & & \\
\hline & PIM6 & 0.68 & & & & & & & \\
\hline \multirow[t]{2}{*}{$\overline{B R}$} & BR1 & 0.80 & \multirow[t]{3}{*}{0.84} & \multirow[t]{3}{*}{0.64} & \multirow[t]{3}{*}{2.54} & \multirow[t]{3}{*}{0.079} & \multirow[t]{3}{*}{0.99} & \multirow[t]{3}{*}{0.99} & \multirow[t]{3}{*}{0.0226} \\
\hline & BR2 & 0.85 & & & & & & & \\
\hline$\alpha=0.842$ & BR3 & 0.75 & & & & & & & \\
\hline \multirow[t]{2}{*}{ SCP } & SCP3 & 0.86 & \multirow[t]{6}{*}{0.89} & \multirow[t]{6}{*}{0.51} & \multirow[t]{6}{*}{3.13} & \multirow[t]{6}{*}{0.001} & \multirow[t]{6}{*}{0.97} & \multirow[t]{6}{*}{0.95} & \multirow[t]{6}{*}{0.0368} \\
\hline & $\mathrm{SCP} 4$ & 0.82 & & & & & & & \\
\hline \multirow[t]{4}{*}{$\alpha=0.853$} & SCP5 & 0.71 & & & & & & & \\
\hline & SCP6 & 0.82 & & & & & & & \\
\hline & SCP7 & 0.70 & & & & & & & \\
\hline & SCP8 & 0.86 & & & & & & & \\
\hline
\end{tabular}

All constructs passed the discriminant validity assessment as square root of AVE was significantly higher than inter construct correlation as shown in Table IV (Wang et al., 2012; Hair et al., 2014).

Table IV: Results of Discriminant Validity

\begin{tabular}{|l|l|l|l|l|l|l|l|l|l|}
\hline Constructs & LS & HRP & QP & SR & CF & SF & PIM & BR & SCP \\
\hline LS & $\mathbf{0 . 8 0 0}$ & & & & & & & & \\
\hline HRP & 0.544 & $\mathbf{0 . 7 1 4}$ & & & & & & & \\
\hline QP & 0.662 & 0.574 & $\mathbf{0 . 7 2 1}$ & & & & & & \\
\hline SR & 0.606 & 0.584 & 0.661 & $\mathbf{0 . 7 3 5}$ & & & & & \\
\hline CF & 0.621 & 0.498 & 0.681 & 0.596 & $\mathbf{0 . 7 7 5}$ & & & & \\
\hline SF & 0.499 & 0.532 & 0.549 & 0.500 & 0.572 & $\mathbf{0 . 7 8 1}$ & & & \\
\hline PIM & 0.591 & 0.636 & 0.661 & 0.689 & 0.563 & 0.565 & $\mathbf{0 . 7 8 7}$ & & \\
\hline BR & 0.572 & 0.335 & 0.586 & 0.432 & 0.553 & 0.336 & 0.407 & $\mathbf{0 . 8 0 0}$ & \\
\hline SCP & 0.634 & 0.347 & 0.556 & 0.458 & 0.571 & 0.366 & 0.383 & 0.643 & $\mathbf{0 . 8 0 0}$ \\
\hline
\end{tabular}

Diagonal values represent the square root of AVE. Off diagonal elements are correlations between constructs

In this study, second-order CFA was conducted for SCQM to confirm that seven constructs i.e., leadership, human resource practices, quality practices, supplier relations: (strategic supplier partnership), customer focus, safety, and process integration and management were sub-constructs of boarder construct of SCQM. Analysis depicted the existence of secondorder construct in accordance with supportive theories of SCQM. No indicator of any sub construct was dropped on the basis of weak factor loading during validation. Also, loading coefficients between the second-order construct and its sub-constructs were also above cut off 
the value of 0.5. QP having highest loading coefficient of 0.84 and SF with the lowest loading coefficient of 0.68 . The overall fit of second-order model was in accordance with the standards with $x^{2} / d f=2.350$, $\mathrm{p}$-value $=0.003, \mathrm{CFI}=0.98, \mathrm{TLI}=0.97$, AGFI $=0.92$ and $\mathrm{SRMR}=0.0290$. The Convergent and Discriminant validities of the second-order construct of SCQM were also evaluated with the same method. Second-order model of SCQM passed the standard of both convergent and discriminant validity with $\mathrm{AVE}=0.60, \mathrm{CR}=0.96$, square root of AVEs was more than correlations between SCQM, SCP, and BR. Also, correlations of SCQM, SCP, and BR are less than 0.85 (Kline, 2005). Based on the overall results of the reliability and validity, it can be concluded that measure models are reliable and valid and fit for further analysis.

The empirical results of structural relationship are shown in Figure 4. Published literature also supports the proposition that these seven factors are observable variables of SCQM. In order to run second-order CFA, first-order factors were taken as endogenous constructs, while secondorder factor SCQM as an exogenous construct. Path analysis of hypothesized structural model was assessed. Same set of fit indices (x2/df, p-value, CFI, TLI and SRMR) were used to analyses measurement model. Multiple fit indexes $x^{2} / d f=2.197$, $\mathrm{p}$-value $=0.000, \mathrm{CFI}=0.95, \mathrm{TLI}=0.94$, $\mathrm{SRMR}=0.0611$, showed reasonable goodness of fit for hypothesized structural model. $\mathrm{p}$-value is sensitive to sample size and assumption of normality (Hu and Bentler, 1999) that's why it is rarely used in empirical studies specifically in operations management/ supply chain literature (Das et al. 2000; Lai, 2003). Researchers have used TLI and CFI as alternative model fit indices. TLI is relatively unaffected by sample size (Hu and Bentler, 1999). Two more fit indices AGFI and RMSEA were also included to confirm model fitness. AGFI $=0.85$ and RMSEA $=0.070$ confirmed the goodness of fit.

Hypothesis testing was performed by path analysis. For path analysis, all the t- values (CR) were above the critical value of $t$-value $>1.96$ for $\mathrm{p}<0.05$ and $>2.33$ for $\mathrm{p}<0.01$ (Kline, 1998), as shown in Table V. SCQM has a strong positive relationship with SCP with path estimate value of 0.825 and t- value 8.563. Hence, it is stated that $\mathrm{H1}$ is supported. Synergies between SCM and QM facilitated this strong relationship. H2 is also supported though t- values for the relationship between SCQM and business results are above standard limit and significant at 0.05 levels but standardized estimate loading value of 0.296 apparently showed weak relationship between both concepts. The relationship between SCP and BR supports H3 by indicating an indirect effect of SCQM on BR through improvement of SCP. To determine the significance of the mediation effect of SCP between SCQM and business results, bootstrapping was also performed (see Table VI). 2000 number of bootstrap samples with 95\% bias-corrected confidence level was used. Significant $(p$-value $<0.05)$ direct and indirect effects have shown partial mediation effect.

Table V: Path analysis results

\begin{tabular}{|l|c|c|c|c|}
\hline Paths & Path Estimates & Standard Error & t- value & P-Value \\
\hline $\mathrm{SCQM} \rightarrow \mathrm{SCP}$ & 0.825 & 0.096 & 8.563 & $* * *$ \\
\hline $\mathrm{SCQM} \rightarrow \mathrm{BR}$ & 0.458 & 0.125 & 3.679 & $* * *$ \\
\hline $\mathrm{SCP} \rightarrow \mathrm{BR}$ & 0.712 & 0.114 & 6.234 & $* * *$ \\
\hline
\end{tabular}

$* * * p$ value $<0.001$ (Two tailed) 
Table VI: Results of bootstrapping

\begin{tabular}{|l|c|c|c|c|c|c|}
\hline Path & \multicolumn{2}{|c|}{ Total effect } & \multicolumn{2}{c|}{ Direct effect } & \multicolumn{2}{c|}{ Indirect effect } \\
\hline & $\begin{array}{l}\text { Std. Est. } \\
\text { loading } \\
\text { coefficients }\end{array}$ & Sig. level & $\begin{array}{l}\text { Std. Est. } \\
\text { loading } \\
\text { coefficients }\end{array}$ & Sig. level & $\begin{array}{l}\text { Std. Est. } \\
\text { loading } \\
\text { coefficients }\end{array}$ & Sig. level \\
\hline SCQM $\rightarrow$ SCP & 0.670 & 0.001 & 0.670 & 0.001 & 0.000 & --- \\
\hline SCQM $\rightarrow$ BR & 0.676 & 0.001 & 0.296 & 0.006 & 0.380 & 0.001 \\
\hline SCP $\rightarrow$ BR & 0.566 & 0.001 & 0.566 & 0.001 & 0.000 & --- \\
\hline$p$-value $<0.05$
\end{tabular}

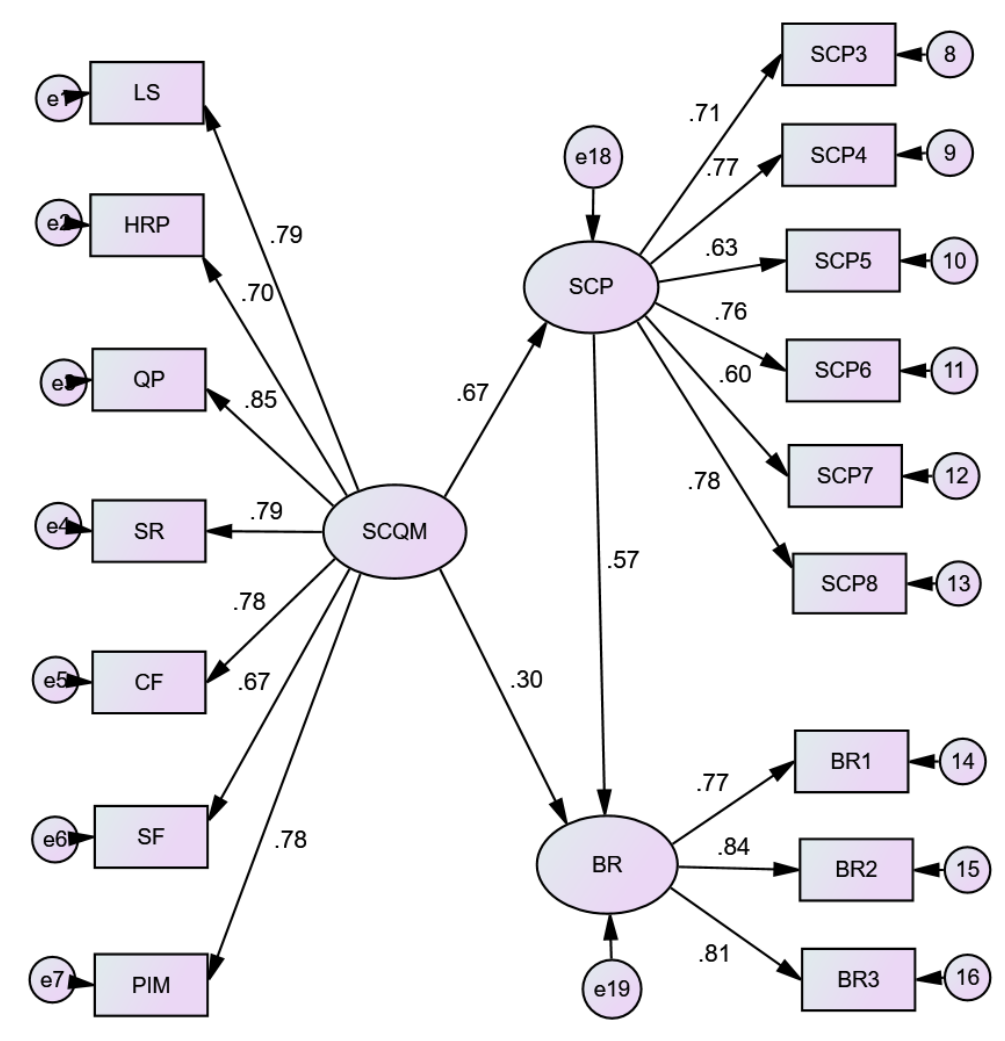

Figure 4: Structural model

\section{Discussion and conclusions:}

This study focuses on SCQM in pharmaceutical sector supply chain, with a survey study in Pakistan. The pharmaceutical manufacturers being a critical node of the healthcare supply chain are targeted. Seven variables of SCQM i.e., leadership, human resource practices, quality practices, supplier relations (strategic supplier partnership), customer focus, safety, process integration and management have been identified from published literature, and empirically established as reliable and valid measures of SCQM in context of Pakistani healthcare sector's pharmaceutical supply chain with a focused group discussions with experts in the sector. SCQM variables along with supply chain performance and business results variables are contextualized 
for healthcare sector pharmaceuticals supply chain. Multiple fit values of $x^{2} / d f=2.197, \mathrm{CFI}=$ $0.95, \mathrm{TLI}=0.94, \mathrm{AGFI}=0.85, \mathrm{SRMR}=0.0616$ confirms the overall fit of SCQM model.

Previously studies of supply chain quality management had been mostly addressing the conceptualization and development of different research frameworks in the subject area. However, published literature on empirical studies is scare. The current study is a step towards empirical execution of conceptual models of supply chain quality management. Results shows agreement with findings of Foster (2008), and Rashid and Aslam (2012), about SCQM dimensions and link of SCQM dimensions with performance (Zeng et al., 2013; Quang et al., 2016). Foster (2008) suggested few dimensions/ critical factors of SCQM in his content analysis study. Only one research paper each mentioning leadership, human resource practices and safety dimension was found but these dimensions are proved to be strong critical factors of SCQM in the findings of this study. Process integration and management as factor of SCQM was missing in the study of Foster (2008) but emerged afterward in SCQM literature. Process integration and management being a critical factor of SCQM is supported by this study.

Healthcare sector supply chains are facing many issues. These issues can be categorized into major categories of forecasting issues, long set up \& lead times, planning \& scheduling issues, poor inventory management and communication problems. Our study confirms the importance of SCQM in addressing all these issues by improving the performance of pharmaceutical supply chains. Mutual relationships between SCQM, SCP and BR are established in the context of the pharmaceutical supply chain of healthcare sector as perceived from literature. However, no full mediating effect of supply chain performance between the SCQM and business results as theoretically proposed by Quang et al. (2016) could be established in this study, but only partial mediation effect was observed. Nevertheless, SCQM has a significant direct effect on both supply chain performance and business results.

Surprisingly, findings of the study regarding logistics costs (transportation and warehousing costs) are not consistent with previous studies of supply chain management and total quality management. Results of transportation cost (loading coefficient $=0.46$ ) and warehousing cost (loading coefficient $=0.43$ ) show that both cost measures are not proved to be valid measures of supply chain performance in the pharmaceutical manufacturing sector. It might be due to the fact that the pharmaceutical manufacturers are often more focused on the technical aspects of cGMP standards for manufacturing and storage of pharmaceuticals as compared to logistics cost-saving activities. However, this result highlights the improvement areas within the pharmaceutical SC. Similarly, variables of employee's evaluation on basis of performance and formal reward system for employees with superior quality performance emerged as a single variable of human resource practices. Furthermore, variables of key supplier involvement in the strategic planning process of organisation and quality of raw materials as priority criteria in the selection of suppliers are emerged as interrelated concepts of supplier relations dimension of SCQM, which proved a wide body of theoretical literature in SCM and TQM

This study offers practitioners of pharmaceutical supply chain insights about the role of leadership, human resource practices, quality practices, supplier relations (strategic supplier 
partnership), customer focus, safety and process integration and management, as critical factors necessary for successful implementation of supply chain quality management in the healthcare sector and combined influence of these factors upon improvement of supply chain performance and business results of the organizations. It encourages managers of pharmaceutical business to adopt SCQM philosophy by focusing on both internal quality and external supply chain perspectives to get a competitive advantage in a complex business environment.

Although integration of quality management and supply chain management has been widely emphasized by the literature in the last twenty years, often total quality management and supply chain management have been studied separately. The gap in the literature was aimed and

partially addressed by this empirical study, in an aim to develop theories regarding the integrated effect of these philosophies especially in the health care sector.

However, the focus of this study has been on manufacturer interface of the pharmaceuticals supply chain, and thus there is a need to provide more understanding regarding other interfaces of the healthcare supply chain. Besides, since this study was conducted in Pharmaceutical industry in Pakistan, cross-cultural differences have not been studied that can affect the generalizability of results.

\section{References:}

Alexander, J. A., Weiner, B. J. and Griffith, J. (2006), "Quality improvement and hospital financial performance", Journal of Organizational Behavior: The International Journal of Industrial, Occupational and Organizational Psychology and Behavior, Vol. 27 No. 7, pp. 1003-1029.

Alt,S. (1997), “Air force JIT deal won’t fly with current rags", Hospital Materials Management, Vol. 22 No. 12, p. 12.

Anderson, J.C. and Gerbing, D.W. (1982), "Some Methods for Respecifying Measurement Models to Obtain Undimensional Construct Measurement", Journal of Marketing Research, Vol. 19, pp. 453-460.

Bastas, A. and Liyanage, K. (2019), "Integrated quality and supply chain management business diagnostics for organizational sustainability improvement”, Sustainable Production and Consumption, Vol. 17, pp. 11-30.

Bayraktar, E., Jothishankar, M.C., Tatoglu, E. and Wu, T. (2007), "Evolution of operations management: past, present and future", Management Research News, Vol. 30 No.11, pp. 843-871.

Benner, M. J. and Veloso, F. M. (2008), "ISO 9000 practices and financial performance: A technology coherence perspective", Journal of Operations Management, Vol. 26 No.5, pp. 611-629.

Blanchard, C., Comm, C.L. and Mathaisel, D.F.X. (2008), "Adding value to service providers: benchmarking Wal-Mart”, Benchmarking: An International Journal, Vol. 15 No.2, pp. 166-177.

Bollen, K.A. (1989), Structural equations with latent variables, Wiley, New York, NY.

Boyer, K.K. and Pronovost, P. (2010), "What medicine can teach operations: what operations can teach medicine", Journal of Operations Management, Vol. 28 No.5, pp. 367-371. 
Buchanan, R. W. and Gillies, C. S. (1990), "Value managed relationships: the key to customer retention and profitability", European Management Journal, Vol. 8 No.4, pp. 523-526.

Byrne, B. (1989), Structural equation modelling with LISREL, PRELIS, and SIMPLIS : Basic concepts, applications, and programming, Psychology Press, Mahwah, N.J.

Cauchick Miguel, P. A. (2006), "Quality management through a national quality award framework: the experience of a hospital in Brazil", The TQM Magazine, Vol.18 No.6, pp. 626-637.

Chai, J., Liu, J. N. and Ngai, E. W. (2013), "Application of decision-making techniques in supplier selection: A systematic review of literature", Expert Systems with Applications, Vol.40 No.10, pp. 3872-3885.

Chang, G. (2009), "Total quality management in supply chain", International Business Research, Vol.2 No.2, pp. 82.

Cresswell, J. W. (2005), Educational research: Planning, conducting and evaluating qualitative and quantitative research, Merrill \& Prentice Hall, NJ.

Creswell, J. W. and Clark, V. L. P. (2017), Designing and conducting mixed methods research, Sage publications.

Das, A., Handfield, R. B., Calantone, R. J. and Ghosh, S. (2000), “A contingent view of quality management-the impact of international competition on quality", Decision Sciences, Vol.31 No.3, pp. 649-690.

Das, A., Pagell, M., Behm, M. and Veltri, A. (2008), "Towards a theory of the linkages between safety and quality", Journal of operations management, Vol.26, pp. 521-535.

De Blok, C., Meijboom, B., Luijkx, K. and Schols, J. (2012), "The human dimension of modular care provision: opportunities for personalization and customization", International Journal of Production Economics, Vol.142 No.01, pp. 16-26.

De Vires, G, Betrand, JWM. and Vissers, JMH. (1999), "Design requirement for health care production control systems", Production Planning \& Control, Vol.19 No.6, pp. 559-569.

Ding, J. M., Jie, F., A. Parton, K. and J. Matanda, M. (2014), "Relationships between quality of information sharing and supply chain food quality in the Australian beef processing industry", The International Journal of Logistics Management, Vol.25 No.1, pp. 85-108.

Evans, J.R. and Berman, B. (2001), "Conceptualizing and operationalizing the business-tobusiness value chain", Industrial Marketing Management, Vol.30 No.2, pp. 135-148.

Fernandes, A. C., Sampaio, P., Sameiro, M. and Truong, H. Q. (2017), "Supply chain management and quality management integration: A conceptual model proposal", International Journal of Quality \& Reliability Management, Vol.34 No.1, pp. 53-67.

Field, A. (2000), Discovering statistics using SPSS for windows, London-Thousand Oaks, New Delhi.

Fish, L.A. (2011), Supply chain quality management, Supply chain Management-Pathways for research and practice, pp. 25-42, available at: https://www.intechopen.com/books/supply-chain-management-pathways-for-researchand-practice/supply-chain-quality-management (assessed on $20^{\text {th }}$ July, 2019).

Flynn, B.B. and Flynn, E.J. (2004), "An exploratory study of the nature of cumulative capabilities”, Journal of Operations Management, Vol. 22, pp. 439-457.

Flynn, B.B. and Flynn, E.J. (2005), "Synergies between supply chain management and quality management: emerging implications", International Journal of Production Research, Vol.43 No.16, pp. 3421-3436. 
Flynn, B. B., Huo, B. and Zhao, X. (2010), "The impact of supply chain integration on performance: A contingency and configuration approach", Journal of Operations Management, Vol.28 No.1, pp. 58-71.

Foster Jr, S.T. (2008), "Towards an understanding of supply chain quality management”, Journal of Operations Management, Vol.26, pp. 461-467.

Foster Jr, S. T. and Ogden, J. (2008), "On differences in how operations and supply chain managers approach quality management", International Journal of Production Research, Vol.46 No.24, pp. 6945-6961.

Foster Jr, S. T., Wallin, C. and Ogden, J. (2011), "Towards a better understanding of supply chain quality management practices", International Journal of Production Research, Vol.49 No.8, pp. 2285-2300.

Fornell, C. and Larcker, D. F. (1981), "Evaluating structural equation models with unobservable variables and measurement error", Journal Of Marketing Research, pp. 39-50.

Frohlich, M. T. (2002), "E-integration in the supply chain: barriers and performance", Decision Sciences, Vol.33 No.4, pp. 537-556.

Gerbing, D. W. and Anderson, J. C. (1993), "Monte Carlo evaluations of goodness-of-fit indices for structural equation models", Sage focus editions, Vol.154, pp. 40-40.

Greene, J.C. and Caracelli, V.J. (1997), Advances in mixed-method evaluation: The challenges and benefits of the integrating diverse paradigms, CA: Jossey-Bass, San Francisco.

Greene, A. and O Rourke, D. (2006), "Lean manufacturing practice in a cGMP environment", Pharmaceutical Technology Europe, Vol.18 No.10, p. 33.

Gunasekaran, A. and McGaughey, R. E. (2003), "TQM is Supply Chain Management", The TQM Magazine, Vol.15 No.6, pp. 361-363.

Hair, J. F., Anderson, R. E., Tatham, R. L. and Black, W. C. (1998), Multivariate Data Analysis, $5^{\text {th }}$ Ed, Prentice-Hall, Englewood Cliffs, NJ.

Hair, J., Black, W., Babin, B. and Anderson, R. (2010), Multivariate Data Analysis, Prentice Hall, Upper Saddle River, NJ.

Hair Jr, J., Sarstedt, M., Hopkins, L. and G. Kuppelwieser, V. (2014), "Partial least squares structural equation modeling (PLS-SEM) An emerging tool in business research", European Business Review, Vol.26 No.2, pp. 106-121.

Hanna, V. and Sethuraman, K. (2005), The diffusion of operations management concepts into the health care sector, Melbourne Business School, Melbourne.

Hendricks, P. S., Wood, S. B. and Hall, S. M. (2009), "Smokers' expectancies for abstinence: Preliminary results from focus groups", Psychology of Addictive Behaviors, Vol.23 No.2, pp. 380.

Heras, I., Casadesús, M. and Dick, G. P. (2002), "ISO 9000 certification and the bottom line: a comparative study of the profitability of Basque region companies", Managerial Auditing Journal, Vol.17 No.1/2, pp. 72-78.

Hitt, L. M., Wu, D. J. and Zhou, X. (2002), "Investment in enterprise resource planning: Business impact and productivity measures", Journal Of Management Information Systems, Vol.19 No.1, pp. 71-98.

Hong, J., Zhihua, Z., Xin, L. and Kwok, H. (2020), "Supply chain quality management and firm performance in China's food industry-the moderating role of social coregulation", International Journal of Logistics Management, Vol.31 No.1, pp. 99-122. 
Hook, B. (2009), “The healthcare industry dilemma”, World Trade: WT 100, Vol. 22 No. 9, pp. 44-45. Available at : http://www.worldtradewt100.com/articles/the-healthcare-industrydilemma (assessed on $10^{\text {th }}$ February, 2019).

$\mathrm{Hu}$, L. T. and Bentler, P. M. (1999), "Cut-off criteria for fit indexes in covariance structure analysis: Conventional criteria versus new alternatives", Structural Equation Modelling: A Multidisciplinary Journal, Vol.6 No.1, pp. 1-55.

Hussain, M., Mehmood, K., Mian, A. and Bilal, A. (2019), "Supply chain quality management and organizational performance", Benchmarking: An International Journal, Vol.27 No.1, pp. 232-249.

Huo, B., Ye, Y., Zhao, X. and Zhu, K. (2016), "Supply chain quality integration: A taxonomy perspective", International Journal of Production Economics, Vol.207, pp. 236-246.

Kannan, V.R. and Tan, K.C. (2005), "Just in time, total quality management, and supply chain management: understanding their linkages and impact on business performance", Omega - International Journal of Management Science, Vol.33 No.2, pp. 153-162.

Kannan, V. R. and Choon Tan, K. (2007), "The impact of operational quality: a supply chain view", Supply Chain Management: An International Journal, Vol.12 No.1, pp. 14-19.

Karamouz, S. S., Kahnali, R. A. and Ghafournia, M. (2020), "Supply chain quality management performance measurement: systematic review", International Journal of Quality \& Reliability Management, Vol. ahead-of-print No. ahead-of-print.

Kaur, M., Singh, K. and Singh, D. (2019), "Synergetic success factors of total quality management (TQM) and supply chain management (SCM)", International Journal of Quality \& Reliability Management, Vol.36 No.6, pp. 842-863.

Kaynak, H. (2003), "The relationship between total quality management practices and their effects on firm performance", Journal of Operations Management, Vol.21 No.4, pp. 405435.

Kaynak, H. and Hartley, J.L. (2008), "A replication and extension of quality management into the supply chain”, Journal of Operations Management, Vol.26 No.4, pp. 468-489.

Kim, H. Y. (2013), "Statistical notes for clinical researchers: assessing normal distribution using skewness and kurtosis", Restorative Dentistry \& Endodontics, Vol.38 No.1, pp. 52-54.

Kline, R. B. (1998), "Software review: Software programs for structural equation modeling: Amos, EQS, and LISREL", Journal of Psychoeducational Assessment, Vol.16 No.4, pp. 343-364.

Kline, R. B. (2005), Principals and practice of structural equation modelling, $2^{\text {nd }}$ Ed., The Guilford Press, New York, NY.

Kuei, C. and Madu, C.N. (2001), "Identifying critical success factors for supply chain quality management", Asia Pacific Management Review, Vol.6 No.4, pp. 409-423.

Kuei, C., Madu, C.N. and Lin, C. (2008), "Implementing supply chain quality management", Total Quality Management and Business Excellence, Vol.19 No.11/12, pp. 1127-1141.

Kuei, C. H., Madu, C. N. and Lin, C. (2011), "Developing global supply chain quality management systems", International Journal of Production Research, Vol.49 No.15, pp. 4457-4481.

Kumar, A., Ozdamar, L. and Zang, C.N. (2008), "Supply chain redesign in the healthcare industry in Singapore", Supply Chain Management: An International Journal, Vol.13 No.2, pp. 95-103. 
Kumar, A., Singh, R. K. and Modgil, S. (2020), "Influence of data-driven supply chain quality management on organizational performance: evidences from retail industry", The TQM Journal, Vol. ahead-of-print No. ahead-of-print.

Kunst, P. and Lemmink, J. (2000), "Quality management and business performance in hospitals: a search for success parameters", Total Quality Management, Vol.11 No.8, pp. 11231133.

Lai, K. H. (2003), "Market orientation in quality-oriented organizations and its impact on their performance", International journal of production economics, Vol.84 No.1, pp. 17-34.

Lanier Jr, D., Wempe, W. F. and Zacharia, Z. G. (2010), "Concentrated supply chain membership and financial performance: Chain-and firm-level perspectives", Journal of Operations Management, Vol.28 No.1, pp. 1-16.

Lanseng, E.J. and Andreassen, T.W. (2007), "Electronic healthcare: a study of people's readiness and attitude toward performing self-diagnosis", International Journal of Service Industry Management, Vol.18 No.4, pp. 394-417.

Lee, S. M., Lee, D. and Schniederjans, M. J. (2011), "Supply chain innovation and organizational performance in the healthcare industry", International Journal of Operations \& Production Management, Vol.31 No.11, pp. 1193-1214.

Lee, S. M., Tae Kim, S. and Choi, D. (2012), "Green supply chain management and organizational performance”, Industrial Management \& Data Systems, Vol.112 No.8, pp. 1148-1180.

Lei, P. W. and Wu, Q. (2007), "Introduction to structural equation modeling: Issues and practical considerations", Educational Measurement: issues and practice, Vol.26 No.3, pp. 33-43.

Li, S., Rao, S. S., Ragu-Nathan, T. S. and Ragu-Nathan, B. (2005), "Development and validation of a measurement instrument for studying supply chain management practices", Journal of Operations Management, Vol.23 No.6, pp. 618-641.

Li, S., Ragu-Nathan, B., Ragu-Nathan, T. S. and Rao, S. S. (2006), "The impact of supply chain management practices on competitive advantage and organizational performance", Omega, Vol.34 No.2, pp. 107-124.

Lin, C., Chow, W., Madu, C., Kuei, C. and Yu, P. (2005), “A structural equation model of supply chain quality management and organizational performance", International Journal of Production Economics, Vol.96 No.3, pp. 355-365.

Lin, C., Kuei, C. H. and Chai, K. W. (2013), "Identifying critical enablers and pathways to high performance supply chain quality management", International Journal of Operations \& Production Management, Vol.33 No.3, pp. 347-370.

Litvak, E and Long, MC. (2000), "Cost and quality under managed care: irreconcilable differences?” The American Journal of Managed Care, Vol.6 No.3, pp. 305-312.

Macinati, M. S. (2008), "The relationship between quality management systems and organizational performance in the Italian National Health Service", Health policy, Vol.85 No.2, pp. 228-241.

Marinkovic, V., Bekcic, S., Pejovic, G., Sibalija, T., Majstorovic, V. and Tasic, L. (2016), “An approach to TQM evaluation in pharma business", The TQM Journal, Vol.28 No.5, pp. 745-759.

Mazzocato, P. (2007), “Applying operations management methods to health care delivery”, Stockolm: Karolinska Institutet.

McCutcheon, D. and Stuart, F.I. (2000), "Issues in the choice of supplier alliance partners", Journal of Operations Management, Vol.18 No.3, pp. 279-303. 
McDonald, R. P. and Ho, M. H. R. (2002), "Principles and practice in reporting structural equation analyses", Psychological methods, Vol.7 No.1, pp. 64-82.

Morgan, D. L. (1993), "Future directions for focus groups", Successful focus groups: Advancing the state of the art, Vol.156, pp. 225-244.

Morton, R. (2003), "Doctors of speed", Transportation and Distribution, Vol.44 No.3, pp. 20-24.

Mustaffa, N.H and Potter, A. (2009), "Healthcare supply chain management in Malaysia: a case study", Supply Chain Management: An International Journal, Vol.14 No.3, pp. 234-243.

Narayana, S.A., Pati, R.K. and Vrat, P. (2012), "Research on management issues in the pharmaceutical industry: A literature review", International Journal of Pharmaceutical and Healthcare Marketing, Vol.6 No.4, pp. 351-375.

Noon, CE, Hankins, CT and Coté, MJ. (2003), "Understanding the impact of variation in the delivery of healthcare services", Journal of Healthcare Management, Vol.48 No.2, pp. 82-97.

Nunnally, J.C. and Bernstein, I.H. (1994), Psychometric Theory, McGraw-Hill, New York, NY.

Pakistan National Health Accounts 2011-12 (2014), Pakistan Bureau of Statistics Government of Pakistan, p. 73.

Pan, T.Z.X. and Pokharel, S. (2007), "Logistics in hospitals: a case study of some Singapore Hospitals", Leadership in Health Services, Vol.20 No.3, pp. 195-207.

Papanicolas I, Woskie LR, and Jha AK. (2018), "Health Care Spending in the United States and Other High-Income Countries", JAMA, Vol.319 No.10, pp. 1024-1039.

Parast, M. M. (2013), "Supply chain quality management: An inter-organizational learning perspective", International Journal of Quality \& Reliability Management, Vol.30 No.5, pp. 511-529.

Parast, M. M. (2020), “A learning perspective of supply chain quality management: empirical evidence from US supply chains”, Supply Chain Management: An International Journal, Vol.25 No.1, pp. 17-34.

Phan, A. C., Nguyen, H. A., Trieu, P. D., Nguyen, H. T. and Matsui, Y. (2019), "Impact of supply chain quality management practices on operational performance: empirical evidence from manufacturing companies in Vietnam”, Supply Chain Management: An International Journal, Vol.24 No.6, pp. 855-871.

Qrunfleh, S. and Tarafdar, M. (2014), "Supply chain information systems strategy: Impacts on supply chain performance and firm performance", International Journal of Production Economics, Vol.147, pp. 340-350.

Quang, H. T., Sampaio, P., Carvalho, M. S., Fernandes, A. C., Binh An, D. T. and Vilhenac, E. (2016), "An extensive structural model of supply chain quality management and firm performance", International Journal of Quality \& Reliability Management, Vol.33 No.4, pp. 444-464.

Rashid, K. and Haris Aslam, M. M. (2012), "Business excellence through total supply chain quality management", Asian Journal on Quality, Vol.13 No.3, pp. 309-324.

Ricci, M.T. and Fraser, H.E. (2006), "Revolution in the pharmaceutical supply chain", Drug Discovery \& Development Magazine, Vol.91 No.11, pp. 42-46.

Robinson, C.J. and Malhotra, M.K. (2005), "Defining the concept of supply chain quality management and its relevance to academic and industrial practice", International Journal of Production Economics, Vol.96 No.3, pp. 315-337.

Saunders, M.N.K., Lewis, P. and Thornhill, A. (2000), "Research Methods for Business Students", Prentice Hall, London. 
Sarrico, C. S. and Rosa, M. J. (2016), "Supply chain quality management in education", International Journal of Quality \& Reliability Management, Vol.33 No.4, pp. 499-517.

Scheller, E.S. and Smeltzer, L.R. (2006), Strategic Management of the Healthcare Supply Chain, Wiley, San Francisco.

Shah, N. (2004), "Pharmaceutical supply chains: key issues and strategies for optimisation", Computers \& Chemical Engineering, Vol.28 No.6-7, pp. 929-941.

Shah, S. C., Rivers, P. A. and Hsu, H. S. (2009), "Strategic information technology alliances for effective health-care supply chain management", Health services management research, Vol.22 No.3, pp. 140-150.

Shah, R., Goldstein, S.M., Unger, B.T. and Henry, T.D. (2008), "Explaining anomalous high performance in a healthcare supply chain”, Decision Sciences, Vol.39 No. 4, pp. 759-789.

Sharma, S., Mukherjee, S., Kumar, A. and Dillon, W. R. (2005), "A simulation study to investigate the use of cut-off values for assessing model fit in covariance structure models", Journal of Business Research, Vol.58 No.7, pp. 935-943.

Shook, C. L., Ketchen Jr, D. J., Hult, G. T. M. and Kacmar, K. M. (2004), “An assessment of the use of structural equation modelling in strategic management research", Strategic management journal, Vol.25 No.4, pp. 397-404.

Sila, I. and Ebrahimpour, M. (2005), "Critical linkages among TQM factors and business results", International journal of operations \& production management, Vol.25 No.11, pp. 1123-1155.

Simchi-Levi, D., Kaminsky, P., Simchi-Levi, E. and Shankar, R. (2008), Designing and managing the supply chain: concepts, strategies and case studies, Tata McGraw-Hill Education, India.

Soares, A., Soltani, E. and Liao, Y. Y. (2017), "The influence of supply chain quality management practices on quality performance: an empirical investigation", Supply Chain Management: An International Journal, Vol.22 No.2, pp. 122-144.

Sroufe, R. and Curkovic, S. (2008), "An examination of ISO 9000: 2000 and supply chain quality assurance", Journal Of Operations Management, Vol.26 No.4, pp. 503-520.

Teoman, S. and Ulengin, F. (2018), "The impact of management leadership on quality performance throughout a supply chain: an empirical study", Total Quality Management \& Business Excellence, Vol.29 No.11-12, pp. 1427-1451.

Thai, V. and Ferry, J. (2018), "The impact of total quality management and supply chain integration on firm performance of container shipping companies in Singapore", Asia Pacific Journal of Marketing \& Logistics, Vol.30 No.3, pp. 605-626.

Tomarken, A.J. and Waller, N.G. (2005), "Structural equation modeling: strengths, limitations, and misconceptions", Annual Review Clinical Psychology, Vol.1 No.1, pp. 31-65.

Trochim, W. M. K. (2006), "Non Probability Sampling. Social Research Methods", available at: http://www.socialresearchmethods.net/kb/sampnon.php. (assessed on 15 th March 2019).

Trochim, W. M. and Donnelly, J. P. (2006), The research methods knowledge base, Atomic Dog, Cincinnati, $\mathrm{OH}$.

Vanichchinchai, A. and Igel, B. (2009), "Total quality management and supply chain management: Similarities and differences", The TQM Journal, Vol.21 No.3, pp. 249-260.

Vanichchinchai, A. and Igel, B. (2011), "The impact of total quality management on supply chain management and firm's supply performance", International Journal of Production Research, Vol.49 No.11, pp. 3405-3424. 
Vissers, J. M., Bertrand, J. W. M. and De Vries, G. (2001), "A framework for production control in health care organizations", Production Planning \& Control, Vol.12 No.6, pp. 591-604.

Wang, C. H., Chen, K. Y. and Chen, S. C. (2012), "Total quality management, market orientation and hotel performance: The moderating effects of external environmental factors", International Journal of Hospitality Management, Vol.31 No.1, pp. 119-129.

Wheaton, B., Muthen, B., Alwin, D. F. and Summers, G. F. (1977), "Assessing reliability and stability in panel models", Sociological Methodology, Vol.8, pp. 84-136.

Wu, L., Chuang, C. H. and Hsu, C. H. (2014), "Information sharing and collaborative behaviors in enabling supply chain performance: A social exchange perspective", International Journal of Production Economics, Vol.148, pp. 122-132.

Yeung, A.C.L. (2008), "Strategic supply management, quality initiatives and organizational performance", Journal of Operations Management, Vol.26, pp. 490-502.

$\mathrm{Yu}, \mathrm{Y}$. and Huo, B. (2018), "Supply chain quality integration: relational antecedents and operational consequences", Supply Chain Management: An International Journal, Vol.23 No.3, pp. 188-206.

Zhang, L., Wang, S., Li, F., Wang, H., Wang, L. and Tan, W. (2011), "A few measures for ensuring supply chain quality", International Journal of Production Research, Vol.49 No.1, pp. 87-97.

Zhou, H., Shou, Y., Zhai, X., Li, L., Wood, C. and Wu, X. (2014), "Supply chain practice and information quality: A supply chain strategy study", International Journal of Production Economics, Vol.147, pp. 624-633.

Zeng, J., Phan, C. A. and Matsui, Y. (2013), "Supply chain quality management practices and performance: an empirical study", Operations Management Research, Vol.6, pp. 19-31.

$\mathrm{Zu}, \mathrm{X}$. and Kaynak, H. (2012), "An agency theory perspective on supply chain quality management", International Journal of Operations \& Production Management, Vol.32 No.4, pp. 423-446. 